\title{
RESOURCES, DYNAMIC CAPABILITIES, AND PERFORMANCE: EVIDENCE FROM POLISH GREEN INNOVATIVE COMPANIES
}

\author{
Magdalena PICHLAK \\ Faculty of Organization and Management, Silesian University of Technology, Zabrze; \\ magdalena.pichlak@polsl.pl, ORCID: 0000-0002-8898-7393
}

\begin{abstract}
Purpose: The paper examines the mediating effect of dynamic capabilities (sensing, seizing, and reconfiguring) on the relationship between critical resources (financial, human, and physical) and Polish green innovative companies' performance.
\end{abstract}

Design/methodology/approach: The paper combines the Resource-Based View of the Firm with Dynamic Capabilities View and applies them to eco-innovation performance. The study is quantitative and was conducted among 54 Polish green innovative companies. Hierarchical regression analysis was used to test the research hypotheses.

Findings: The results indicate that sensing and seizing opportunities mediate the relationship between all types of resources and eco-innovators' performance. Moreover, reconfiguring the resource base mediates the relationship between human resources and Polish green innovative companies' economic output.

Research limitations/implications: The results of the study indicate that a specific set of resources is not always enough to enhance green innovative companies' performance. Therefore, there is a need for dynamic capabilities. Such capabilities lead to the development of resources and their dynamic adaptation to technological and market changes. The findings may contribute to a broader scientific discussion on the specificity of eco-innovative activity and its conditions in the Polish economy.

Originality/value: The paper is the first to examine - to the author's best knowledge the mediating effect of multidimensional dynamic capabilities on the relationship between critical resources and Polish green innovative companies' performance.

Keywords: resources; dynamic capabilities; performance; eco-innovation.

Category of the paper: Research paper.

\section{Introduction}

Frequently used in academic research, the Resource-Based View (RBV) emphasizes the importance of the firm's resources as the basis for gaining competitive advantage (Barney, 1991; Epelbaum, and Martinez, 2014; Andersén, 2021). RBV (which is relatively static) 
considers the firm as a set of diverse resources that differentiate it from its competitors. Moreover, this approach assumes that these resources are heterogeneously distributed among competing firms (Helfat, and Peteraf, 2003; Li-Ying et al., 2016). An extension of the RBV is the Dynamic Capabilities View (DCV), which (consistent with its dynamic nature) describes how a company's resources evolve to provide a relatively sustainable competitive advantage (Teece, 2007; Liao et al., 2017). Several alternative approaches to dynamic capabilities have been offered in the literature (Teece et al., 1997; Eisenhardt, and Martin, 2000; Zollo, and Winter, 2002; Zahra et al., 2006). These views differ concerning the nature of dynamic capabilities, their role, their effects, and the context they are developed (cf. Barreto, 2010). Despite the existing differences, most researchers agree on the purpose of building dynamic capabilities as a response to a changing environment.

As companies operate in a constantly changing environment (characterized by unpredictability and discontinuity), there is a need to build dynamic capabilities. It is particularly important in developed countries (e.g. EU countries), where companies have to deal with the technological changes and the increasingly environmental challenges generated by growing emissions of pollutants. The increasing scope of environmental restrictions, including high and unstable energy prices, restrictiveness of environmental regulations (resulting from the European Green Deal adopted by the European Commission), and the growing ecological awareness of consumers imply the need to include environmental issues in companies' activities. In such conditions, excessive concentration only on the resources may lead to in Leonard-Barton's (1992) terminology - core rigidities, i.e. restriction of the scope and directions of their future development.

The paper attempts to make a value-added contribution by integrating RBV and DCV and extending them to the eco-innovation literature. The paper's objective is to empirically examine the relationship between key resources, dynamic capabilities, and performance among the 54 most innovative companies in Poland that develop globally new green technology solutions.

The results of the studies conducted in the literature indicate that, compared to conventional innovation, eco-innovation requires a more significant commitment of resources (Horbach, 2008; Zhang, and Walton, 2017) and their new combinations due to the higher level of uncertainty of the generated ecological solutions (Poznańska, 2018). Moreover, the specific nature of these innovations and the resources used in their development create a 'natural' imitation barrier for competitors. Second, the diversity of eco-innovative changes indicates that green strategies are not limited to maintaining the status quo but include proactive actions to anticipate future regulations or consumer demands (Klewitz, and Hansen, 2014). Such a posture, as Meredith (1995) notes, constitutes a defensive strategy of a proactive nature and, by definition, requires specific capabilities through which firms can build, integrate, and reconfigure their resources, adapt them to a changing environment, and transform them into efficiencies (cf. Bartoszczuk, 2018; Wysocki, 2019). Simultaneously, despite the growing 
number of studies treating the importance of dynamic capabilities, many researchers (Ambrosini et al., 2009; Easterby-Smith et al., 2009; Barreto, 2010) emphasize that the concept still needs empirical confirmation. Moreover, embedding a multidimensional view of dynamic capabilities in eco-innovation (at the micro-level of analysis) is a matter explored to a relatively limited extent (del Rio et al., 2016; Hazarika, and Zhang, 2019). This study seeks to fill this gap in theoretical (research framework) and empirical (verification of research hypotheses) layers.

\section{Theoretical Framework}

\subsection{Resource-Based View and Dynamic Capabilities View}

Both RBV and DCV are very popular in the literature for explaining the sources of a firm's competitive advantage and enhancing performance. The RBV, developed by Penrose (1959), argues that a firm's competitive advantage is determined by its critical resources, which, according to Barney's VRIN framework, should be: valuable (should have value), rare, and firm-specific (meaning that they cannot be widely distributed in a given sector and must be closely identifiable with a specific firm, making them difficult for competitors to acquire), imperfectly imitable (due to their intangible and unique nature), and non-substitutable. Resources are categorized in the literature into several specific typologies and include financial resources, human resources, physical resources, and technological resources (Grant, 1991). The other typology is to distinguish tangible resources (financial and physical) and intangible re-sources (del Río et al., 2016), including the qualifications and skills of organizational members that require learning and accumulating difficult to replicate experiences.

The RBV perspective, although sometimes criticized for being tautological (Chahal et al., 2020), provides an effective strategy based on the unique resources that define the firm position relative to competitors (Li-Ying et al., 2016). The assumption of the leading role of critical resources and the explanation of their synergistic impact on firm performance are also the basis of other related theories, i.e., Knowledge-Based View of the Firm (KBV) (Grant, 1996); Relational RBV (Andersén, 2021) according to which resources can extend beyond organizational boundaries and can be embedded in inter-organizational activities and procedures; and Natural RBV (Hart, 1995; Hart, and Dowell, 2010) which emphasizes the environmental impact of firm's resources.

Since RBV is relatively static and fails to explain the sources of a company's competitive advantage operating in a dynamically changing environment (Barreto, 2010), the Dynamic Capabilities View (Teece et al., 1997; Teece, 2007; Liao et al., 2017) has attracted increasing attention from researchers. This view suggests that resources can be a source of competitive advantage only to the extent that a firm can develop, integrate, and configure them using 
specific capabilities. Because DCV is based on similar assumptions as RBV, researchers conceptualize them as complementary perspectives that explain the multidimensional effects of resource configuration on firm performance (Ambrosini, and Bowman, 2009; Li-Ying et al., 2016).

\subsection{Conceptualization of Dynamic Capabilities}

The literature emphasizes that dynamic capabilities are a subset of a broader construct organizational capabilities (Wojcik-Karpacz, 2017), defined by Helfat and Peteraf (2003, p. 999) as the abilities 'to perform a coordinated set of tasks, utilizing organizational resources, for the purpose of achieving a particular end result'. Following the impact of capabilities on the company's development, dynamic capabilities (second-order capabilities) can be distinguished from operational capabilities (ordinary, substantial, functional, first-order). Teece et al. (2016) indicate that a firm's ordinary capabilities are a measure of its technical fitness and, by definition, do not prevent creative destruction processes. Developing the typology proposed by Collis (1994) and relating it to innovation, Danneels (2002) distinguishes (1) first-order capabilities that involve the tangible and intangible resources needed for innovation, and (2) second-order capabilities (dynamic capabilities) crucial to identify, evaluate, and incorporate new technological and customer competences, as well as new knowledge and skills that lie beyond the specific domain. Similarly, Ambrosini et al. (2009) capture the first category as the resource base, and Winter (2003) suggests that building higher-order capabilities depends on the costs and benefits of investments relative to ad hoc problem-solving.

The most commonly cited definition of dynamic capabilities provided by Teece et al. (1997, p. 516) states that dynamic capabilities are 'the firm's ability to integrate, build, and reconfigure internal and external competencies to address rapidly changing environments'. The researchers emphasize the role of path dependencies, and organizational learning, referring to the evolutionary perspective. Moreover, they argue that dynamic capabilities are usually built rather than bought; hence (as in RBV), they are heterogeneous and can be a source of relatively sustainable competitive advantage in a rapidly changing market environment (Teece et al., 1997; Teece, 2007; Barreto, 2010).

A different research context adopted by Eisenhardt and Martin (2000) indicates that the nature of dynamic capabilities depends on the firms' environment characteristics. In moderately dynamic markets, dynamic capabilities can be viewed as organizational routines; in highvelocity markets, they manifest as simple, highly experiential, and fragile processes that rely on rapidly created new knowledge.

The paper refers to the most popular in the literature view of dynamic capabilities by Teece et al. (1997) and Teece (2007), who distinguish sensing, seizing, and reconfiguring capabilities. Building on the studies of Wilden et al., (2013), and Fainshmidt and Frazier (2017), it is assumed that sensing and seizing are immanently related; moreover, as Danneels (2016) argues, they can even be captured as antecedents of resource reconfiguration. 
Sensing involves scanning, searching, and exploring both technological and market changes. It requires maintaining close relationships with customers, suppliers, and R\&D partners, and other stakeholders (Wilden et al., 2013) and understanding latent demand, the structural evolution of sectors and markets, and the anticipated responses of various parties (Teece, 2007). Seizing involves evaluating and exploiting identified technological and market opportunities. It requires investing in selected projects and technologies that are most likely to be accepted by the market (Teece, 2007; Wilden et al., 2013). Finally, once an opportunity is identified, the firm may need to reconfigure its resources to adapt to the changing reality. Reconfiguring, therefore, involves a firm's ability to recombine and reconfigure its resources in response to both internal and external changes (Teece, 2007). The described conceptualization of dynamic capabilities is well-established. It has been used both in theoretical (Teece, 2007; Fallon-Byrne, and Harney, 2017) and empirical studies (Wilden et al., 2013; Gajendran et al., 2014; Fainshmidt, and Frazier, 2017). Therefore, it was also used in the empirical studies presented in this paper.

\section{Research model and hypotheses}

Pacheco et al. (2017) indicate that financial, human, and physical resources are crucial for eco-innovation. Based on the systematic literature review, the researchers conclude that generating new solutions is connected to organizational R\&D expenditures. Similarly, Horbach (2008), Segarra-Oña et al. (2011), and Doran and Ryan (2016) argue that the total spending increasing the stock of technical knowledge (as a result of undertaking R\&D activities) determines the eco-innovative orientation of firms. Regarding human resources, Bossle et al. (2016) and Damanpour (1991) note that the diversity of skills and experiences of organizational members allows for the creation of more diverse teams in which innovation (and ecoinnovation) is more likely to be generated. Del Brío and Junquera (2003) emphasize the need for training organizational members to strengthen their environmental awareness, and Dangelico (2016) highlights the critical role of recruiting environmental professionals. Similarly, Triguero et al. (2013) indicate that highly qualified staff (including managers and employees with environmental knowledge) increases eco-innovation. Effective eco-innovation activities also require physical resources, including machines and equipment, laboratories, and other R\&D units and technical infrastructure, i.e., energy and infrastructure facilities, essential in high-technology sectors. Physical resources ensure the protection of organizational processes from disruptions (Lichtarski, 2007) and their stability, reflected in the continuity of conducted eco-innovative activities. 
However, a firm's resources may lose the VRIN characteristic in a dynamically changing environment. Failure to match resources to changing external conditions may result in core rigidity (Leonard-Barton, 1992). Based on the Dynamic Capabilities View, this paper assumes that all interrelated dimensions of dynamic capabilities - i.e., sensing and seizing opportunities as well as reconfiguring the firm's resource base - enhance the efficiency of resource allocation necessary for eco-innovation performance (figure 1).

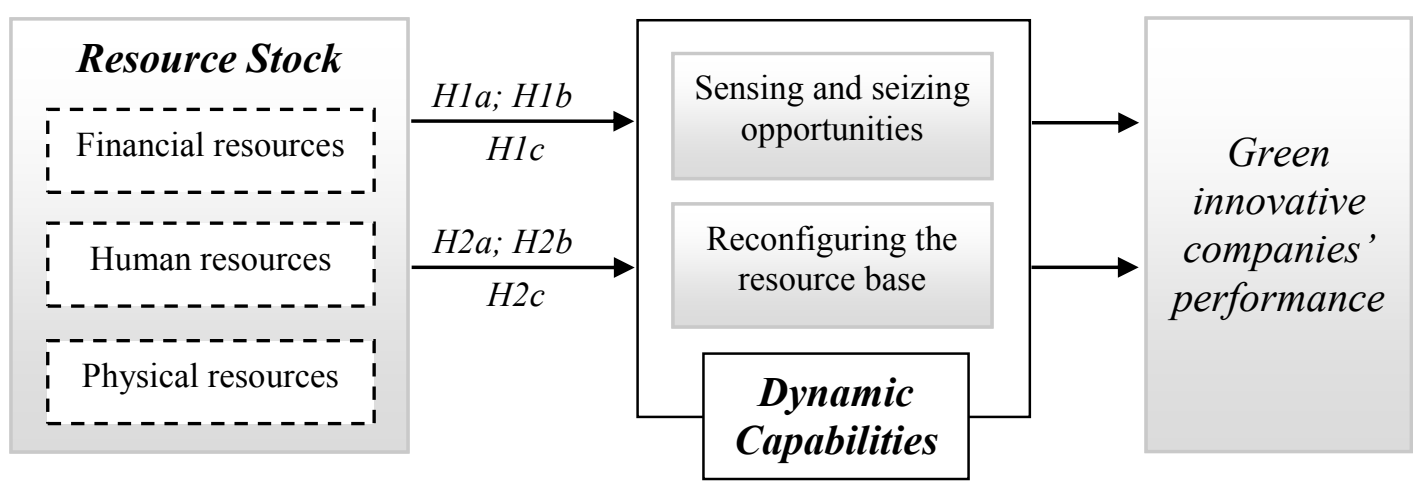

Figure 1. Theoretical framework.

Sensing and seizing opportunities are critical for effective innovation development (Gajendran et al., 2014; Liao et al., 2017). Such activities do not occur independently of a firm's existing resource base (Teece, 2007; Wilden et al., 2013). Instead, they result from the knowledge and skills of employees and the financial and physical resources within the firm. Without a critical base of resources, a company lacks the essential ingredients to enter into effective relationships with customers, suppliers, and universities, participate in professional associations, and follow best practices (Teece, 2007; Wilden et al., 2013). Often, it is possessed resources that make a firm more responsive and take full advantage of the opportunities and threats in its environment (Liao et al., 2017). For example, better technical equipment and higher levels of R\&D investment enable firms to pursue multiple green research projects simultaneously. Such a strategy often leads to their crossover. A condition for this strategy is developing innovative human resources, embodying the creativity of organization members with their expertise in specific domains.

On the other hand, both sensing and seizing are crucial to mobilize the resources necessary for the effective generation of eco-innovation (Dangelico et al., 2013; Huang, and Li, 2017). Firms that scan and explore the environment for technological and market changes and then seize the identified opportunities can increase their environmental knowledge and strengthen the efficiency of their use of financial and physical capital. In summary, the greater a firm's ability to sense and seize opportunities, the greater the degree of resource utilization. Based on the above argumentation, it can therefore be assumed that:

H1: Sensing and seizing opportunities mediate the relationship between (a) financial resources; (b) human resources; (c) physical resources and green innovative companies' performance. 
Reconfiguring involves recombining the existing resource base to respond to technological and market changes (Teece, 2007). Besides, because resources are generally dispersed within a firm, reconfiguration requires efficient communication and employee engagement (Fainshmidt, and Frazier, 2017) and internal accumulation and mobilization of financial and physical resources (Gajendran et al., 2014). Reconfiguring capabilities support firms in maintaining evolutionary fitness (Zhou et al., 2019) and strengthening organizational change (Gajendran et al., 2014; Dangelico et al., 2017), leading to increased efficiency of the resource base. This occurs through intra-organizational knowledge sharing, including but not limited to establishing new departments focused on creating eco-innovation or interdisciplinary teams dedicated to developing new environmental technologies (Dangelico et al., 2017). In summary, the greater a firm's ability to recombine and reconfigure financial, human, and physical resources, the greater the degree to which they are effectively used in the process of generating eco-innovation. Based on the above argumentation, it can therefore be assumed that:

H2: Reconfiguring the resource base mediates the relationship between (a) financial resources; (b) human resources; (c) physical resources and green innovative companies' performance.

\section{Research methodology}

To test the developed research hypotheses, a survey was conducted among 54 of the most eco-innovative Polish companies. The respondents are the winners of the 2009-2015 Program of the Ministry of Climate and Environment 'GreenEvo Green Technology Accelerator' (1st round of research) as well as they were selected by the Specialist Observatory in Technologies for Environmental Protection (2nd round of research). This research is part of a re-search project on eco-innovation management in Polish companies and was carried out in early 2019 using the CATI (Computer Assisted Telephone Interview) method. Due to the desire to research the most eco-innovative Polish companies, a non-random sampling was decided. However, this results in limited representativeness of the sample due to its purposeful selection and relatively small size.

The measurement scales used in the conducted survey research are derived from the literature and include statements concerning multidimensional dynamic capabilities, resources, and performance of the companies. For measuring sensing and seizing, the operationalization by Wilden et al. (2013) was used. An important reason for the choice was that the developed scales were retested (for reliability and validity) and then used in a study by Fainshmidt and Frazier (2017). To measure reconfiguring, a research scale developed two years later by Wilden and Gudergan (2015) was adapted. This scale is more detailed than the 2013 scale and therefore 
captures a broader range of issues. All items were measured on an interval Likert scale ranging from 1 - 'strongly disagree' to 7 - 'strongly agree' with a statement.

The estimated level of R\&D expenditures measured financial resources compared to the main competitors in the sector; human resources - the number of eco-innovative employees in the total number of organizational members, and physical resources - owned machinery and equipment, technical infrastructure and laboratories, and other R\&D units compared to the main competitors in the sector. A similar measurement of resources was used in their study by $\mathrm{Xu}$ et al. (2010) and Pichlak (2012).

Finally, the performance measurement was based on five statements relating to average net profit rate, return on equity, return on assets, return on sales, and the ability to finance growth from profits in 2017-2019. The measurement scale used is an operationalization of the performance developed by Eddleston et al. (2008). Again, a seven-point Likert scale was used - respondents were asked to rate their own company compared to major competitors in the sector (from 1 - 'much worse' to 7 - 'much better').

\section{Analyses and Results}

The first step in data analysis was to conduct a Confirmatory Factor Analysis (CFA) to check the proposed structure of dynamic capabilities. The results showed that the values of the chi-square statistic do not exceed three times the number of degrees of freedom, which is an acceptable result. Moreover, the approximation errors (RMSEA) remain below the limit level of 0.1 , while TLI and CFI exceed or are close to 0.9 . The obtained results indicate that the degree of matching of the model to empirical data is satisfactory.

In the next step, a reliability and validity analysis of the measurement scales was conducted. For this purpose, the following parameters were estimated: Cronbach's Alpha (CA), composite reliability (CR), average variance extracted (AVE), and maximum shared variance (MSV). The analysis showed that the reliability parameters (CA and CR) exceeded the thresholds of 0.7 (Wilden, and Gudergan, 2015), whereas the AVE reached values above the required threshold of 0.5 (Wilden et al., 2013). Moreover, the condition assuming that AVE should be higher than MSV was met. The results of the reliability and validity analysis are presented in Table 1.

Table 1.

Reliability of the measurement scales

\begin{tabular}{|l|c|c|c|c|c|c|}
\hline \multicolumn{1}{|c|}{ Construct } & Mean & SD & CA & CR & AVE & MSV \\
\hline Sensing capability & 4.42 & 1.17 & 0.725 & 0.815 & 0.527 & 0.069 \\
\hline Seizing capability & 5.69 & 0.48 & 0.825 & 0.854 & 0.595 & 0.069 \\
\hline Reconfiguring capability & 3.45 & 0.97 & 0.863 & 0.878 & 0.510 & 0.048 \\
\hline
\end{tabular}


In summary, the analysis showed that all scales have a satisfactory level of validity and reliability.

To test the research hypotheses, an analysis based on hierarchical regression models was conducted. Following Aiken and West (1991), the variables were centered to reduce the potential problem of multi-collinearity. Table 2 shows the results of hierarchical multiple regression.

\section{Table 2.}

The results of the Hierarchical Regression Analysis

\begin{tabular}{|c|c|c|c|c|c|c|c|c|c|}
\hline & \multirow{2}{*}{\multicolumn{2}{|c|}{$\begin{array}{c}\begin{array}{c}\text { Mediation - } \\
\text { Condition I }\end{array} \\
\text { Model } 1\end{array}$}} & \multicolumn{4}{|c|}{ Mediation - Condition II } & \multirow{2}{*}{\multicolumn{2}{|c|}{$\begin{array}{c}\begin{array}{c}\text { Mediation - } \\
\text { Condition III }\end{array} \\
\text { Model } 3\end{array}$}} \\
\hline & & & & \multicolumn{2}{|c|}{ Model 2A } & \multicolumn{2}{|c|}{ Model 2B } & & \\
\hline & & $\beta$ & $\mathbf{p}$ & $\beta$ & p & $\beta$ & $\mathbf{p}$ & $\beta$ & p \\
\hline \multirow{4}{*}{$\begin{array}{l}\text { Control } \\
\text { Variables }\end{array}$} & Firm Age $^{\wedge}$ & 0.139 & 0.295 & 0.046 & 0.774 & 0.424 & 0.010 & 0.041 & 0.756 \\
\hline & Firm Size $^{\wedge}$ & -0.386 & 0.031 & -0.204 & 0.341 & -0.200 & 0.343 & -0.288 & 0.080 \\
\hline & Techn. domain 1 & -0.132 & 0.274 & -0.110 & 0.452 & 0.032 & 0.823 & -0.111 & 0.315 \\
\hline & Techn. domain 2 & -0.055 & 0.639 & -0.114 & 0.422 & -0.064 & 0.645 & -0.007 & 0.948 \\
\hline \multicolumn{2}{|c|}{ Financial Resources } & -0.345 & 0.049 & 0.373 & 0.073 & 0.095 & 0.603 & 0.266 & 0.051 \\
\hline \multicolumn{2}{|c|}{ Human Resources } & 0.425 & 0.021 & 0.348 & 0.041 & 0.378 & 0.043 & 0.435 & 0.060 \\
\hline \multicolumn{2}{|c|}{ Physical Resources } & 0.260 & $\mathbf{0 . 0 3 6}$ & 0.377 & 0.048 & -0.103 & 0.633 & 0.176 & 0.302 \\
\hline \multirow{2}{*}{ Mediators } & Sensing and seizing & & & & & & & 0.269 & $\mathbf{0 . 0 3 0}$ \\
\hline & Reconfiguring & & & & & & & 0.213 & $\mathbf{0 . 0 3 4}$ \\
\hline \multicolumn{2}{|l|}{$\mathbf{R}^{\mathbf{2}}$} & 0.442 & & 0.375 & & 0.325 & & 0.671 & \\
\hline \multicolumn{2}{|l|}{$\Delta \mathbf{R}^{2}$} & 0.357 & & 0.280 & & 0.222 & & 0.594 & \\
\hline \multicolumn{2}{|l|}{$\mathrm{F}(7,46)$} & 5.203 & & 4.391 & & 2.596 & & 5.728 & \\
\hline \multicolumn{2}{|l|}{ p } & 0.000 & & 0.001 & & 0.024 & & 0.000 & \\
\hline
\end{tabular}

$\wedge$ natural logarithm. Technological domain: 1 - Water and sewage management. Technological domain 2 - Biodiversity conservation. The estimation of the parameters for adjusting models to empirical data is based on the use of the least squares' method.

The data presented in Table 2 show that the direct relationships between financial, human, and physical resources and Polish green innovative companies' performance are statistically significant (Model 1). This result represents the first mediation condition's fulfillment according to the standard procedure proposed by Baron and Kenny (1986). The estimation of Model 2A indicates that the relationship between human and physical resources and the mediating variable (sensing and seizing opportunities) is statistically significant at the probability level of $0.041(\beta=0.348)$ and $0.048(\beta=0.377)$, respectively. Regarding financial resources, given the small size of the research sample, the estimation of model 2A only allows to assume that there is a tendency for these resources to directly affect the analyzed dimensions of dynamic capabilities $(\beta=0.373, p=0.073$ ). Moreover, the results of model $2 \mathrm{~B}$ (estimated for reconfiguring) indicate that only human resources directly affect the third dimension of dynamic capabilities $(\beta=0.378, p=0.043)$. Such results represent a partial fulfillment of the second condition of mediation, according to which the relationship between independent variables and mediators should be statistically significant.

Essential for testing the research hypotheses is the estimation of model 3 showing the fulfillment of the third condition of mediation, according to Baron and Kenny (1986). This condition states that the relationship between the independent variables and the dependent 
variable should be weaker after the mediating variables are included in the model. The mediation analysis results (Model 3) indicate that the relationship between sensing and seizing opportunities and performance is statistically significant at $p=0.030(\beta=0.269)$. Such results - In the absence of statistically significant relationships between the independent variables (resources) and the dependent variable (performance) - confirm Hypothesis H1 assuming that sensing and seizing opportunities mediate the relationship between (a) financial resources; (b) human resources; (c) physical resources, and green innovative companies' performance. On the other hand, the existence of a direct and statistically significant relationship between reconfiguring and performance $(\beta=0.213, p=0.034)$ and the absence of a relationship between resources and performance (Model 3) only confirms Hypothesis H2b assuming that reconfiguring the resource base mediates the relationship between human resources and green innovative companies' performance. As mentioned earlier, concerning financial and physical resources, the second mediation condition in Model 2B was not found. Therefore, the obtained results do not confirm Hypotheses $\mathrm{H} 2 \mathrm{a}$ and $\mathrm{H} 2 \mathrm{c}$ assuming that reconfiguring the resource base mediates the relationship between financial and physical resources, and green innovative companies' performance.

\section{Discussion and Conclusion}

The objective of the paper was to empirically examine the relationship between crucial resources, dynamic capabilities, and eco-innovators performance. Based on Teece et al. (1997) and Teece (2007), the paper focuses on examining the mediating role of dynamic capabilities (sensing and seizing, reconfiguring) on the relationship between financial, human, and physical resources and the performance of Polish green innovative companies.

The results indicate that sensing and seizing mediate the relationship between all types of resources (financial, human, and physical) and firms' performance. Such results confirm the theoretical findings according to which sensing capability (related to scanning, searching, and exploring technological and market changes) strengthens the use of various resources. It allows the collection of information necessary for the effective generation of eco-innovation by learning about markets, customers, competitors, and the external environment (Horbach, 2008; del Rio et al., 2016; Doran, and Ryan, 2016; Sopińska, and Dziurski, 2018). Similarly, seizing capability (related to systemic assessment of existing capabilities) (Wilden et al., 2013; Gajendran et al., 2014; Liao et al., 2017) entails making investments in owned tangible and intangible assets (Fainshmidt, and Frazier, 2017).

Surprisingly, the results indicate that reconfiguring mediates the relationship between human resources and Polish green innovative companies' performance. Thus, it appears that employees' environmental knowledge (as a result of sensing and seizing opportunities) most 
likely triggers subsequent resource reconfiguration processes and thereby reduces organizational inertia. In other words, reconfiguring capability generates value by building problem teams, periodically changing the organizational structure, etc. All these actions extend the knowledge necessary for developing new green technological solutions. Moreover, such results confirm the findings of other studies according to which attitudes, behaviors, and interpersonal relationships among organizational members are essential factors that enable reconfiguration (Fainshmidt, and Frazier, 2017). It is the knowledge of employees that facilitates the mobilization of relevant resources when there is a real need to make organizational changes.

In summary, the study results indicate that dynamic capabilities (representing a company's potential for systematic problem solving) may determine the effective use of resources crucial for generating eco-innovation. Such results may be an important indication for management practice despite several of their limitations (purposeful selection of the research sample and its small size and subjective methods of measuring variables). Thus, an extension of the analysis and the most important direction for future research may be to conduct longitudinal studies as well as repeat quantitative research in other contexts and on other (larger) populations.

The findings presented in this paper support the argument of Eisenhardt and Martin (2000) that firms with similar dynamic capabilities may create and develop different bundles of resources and consequently have different levels of performance. It is essential concerning Polish green innovative companies, whose activities are conditioned not only by institutional pressure (Green Deal) but also by the need for a more significant commitment of resources than the development of conventional innovation.

\section{References}

1. Aiken, L.S., and West, S.G. (1991). Multiple Regression: Testing and Interpreting Interactions. Newbury Park, CA: Sage Publications.

2. Ambrosini, V., and Bowman, C. (2009). What are dynamic capabilities and are they a useful construct in strategic management? International Journal of Management Reviews, Vol. 11(1), pp. 29-49. doi: 10.1111/j.1468-2370.2008.00251.x.

3. Ambrosini, V., Bowman, C., and Collier, N. (2009). Dynamic Capabilities: An Exploration of How Firms Renew their Resource Base. British Journal of Management, Vol. 20(1), pp. 9-24. doi: 10.1111/j.1467-8551.2008.00610.x.

4. Andersén, J. (2021). A relational natural-resource-based view on product innovation: The influence of green product innovation and green suppliers on differentiation advantage in small manufacturing firms. Technovation. doi: 10.1016/j.technovation.2021.102254. 
5. Barney, J. (1991). Firm Resources and Sustained Competitive Advantage. Journal of Management, Vol. 17(1), pp. 99-120. doi: 10.1177/014920639101700108.

6. Baron, R.M., and Kenny, D.A. (1986). The moderator-mediator variable distinction in social psychological research: Conceptual, strategic, and statistical considerations. Journal of Personality and Social Psychology, Vol. 51(6), pp. 1173-1182. doi: 10.1037/00223514.51.6.1173.

7. Barreto, I. (2010). Dynamic Capabilities: A Review of Past Research and an Agenda for the Future. Journal of Management, Vol. 36(1), pp. 256-280. doi: 10.1177/0149206309350776.

8. Bartoszczuk, P. (2018). Mechanizmy powstawania efektów ekoinnowacji w przedsiębiorstwach $w$ Polsce. Warszawa: Oficyna Wydawnicza SGH.

9. Bossle, M.B., de Barcellos, M.D., Vieira, L.M., and Sauvée, L. (2016). The drivers for adoption of eco-innovation. Journal of Cleaner Production, Vol. 113, pp. 861-872. doi: 10.1016/j.jclepro.2015.11.033.

10. Chahal, H., Gupta, M., Bhan, N., and Cheng, T.C.E. (2020). Operations management research grounded in the resource-based view: A meta-analysis. International Journal of Production Economics, Vol. 230. doi: 10.1016/j.ijpe.2020.107805.

11. Collis, D.J. (1994). Research Note: How Valuable are Organisational Capabilities? Strategic Management Journal, Vol. 15(S1), pp. 143-152. doi: 10.1002/smj.4250150910.

12. Damanpour, F. (1991). Organizational Innovation: A Meta-Analysis Of Effects Of Determinants and Moderators. Academy of Management Journal, Vol. 34(3), pp. 555-590. doi: $10.5465 / 256406$.

13. Dangelico, R.M. (2016). Green Product Innovation: Where we are and Where we are Going. Business Strategy and the Environment, Vol. 25(8), pp. 560-576. doi: 10.1002/bse.1886.

14. Dangelico, R.M., Pontrandolfo, P., and Pujari, D. (2013). Developing Sustainable New Products in the Textile and Upholstered Furniture Industries: Role of External Integrative Capabilities. Journal of Product Innovation Management, Vol. 30(4), pp. 642-658. doi: 10.1111/jpim.12013.

15. Dangelico, R.M., Pujari, D., and Pontrandolfo, P. (2017). Green Product Innovation in Manufacturing Firms: A Sustainability-Oriented Dynamic Capability Perspective. Business Strategy and the Environment, Vol. 26(4), pp. 490-506. doi: 10.1002/bse.1932.

16. Danneels, E. (2002). The dynamics of product innovation and firm competences. Strategic Management Journal, Vol. 23(12), pp. 1095-1121. doi: 10.1002/smj.275.

17. Danneels, E. (2016). Survey measures of first-and second-order competences. Strategic Management Journal, Vol. 37(10), pp. 2174-2188. doi: 10.1002/smj.2428.

18. del Brío, J.Á., and Junquera, B. (2003). A Review of the literature on environmental innovation management in SMEs: implications for public policies. Technovation, Vol. 23(12), pp. 939-948. doi: 10.1016/s0166-4972(02)00036-6. 
19. del Río, P., Peñasco, C., and Romero-Jordán, D. (2016). What drives eco-innovators? A critical review of the empirical literature based on econometric methods. Journal of Cleaner Production, Vol. 112, pp. 2158-2170. doi: 10.1016/j.jclepro.2015.09.009.

20. Doran, J., and Ryan, G. (2016). The Importance of the Diverse Drivers and Types of Environmental Innovation for Firm Performance. Business Strategy and the Environment, Vol. 25(2), pp. 102-119. doi: 10.1002/bse.1860.

21. Easterby-Smith, M., Lyles, M.A., and Peteraf, M.A. (2009). Dynamic Capabilities: Current Debates and Future Directions. British Journal of Management, Vol. 20, pp. S1-S8. doi: 10.1111/j.1467-8551.2008.00609.x.

22. Eddleston, K.A., Kellermanns, F.W., and Sarathy, R. (2008). Resource Configuration in Family Firms: Linking Resources, Strategic Planning and Technological Opportunities to Performance. Journal of Management Studies, Vol. 45(1), pp. 26-50. doi: 10.1111/j.14676486.2007.00717.x.

23. Eisenhardt, K.M., and Martin, J.A. (2000). Dynamic capabilities: what are they? Strategic Management Journal, Vol. 21(10-11), pp. 1105-1121. doi: 10.1002/10970266(200010/11)21:10/11<1105::aid-smj133>3.0.co;2-e.

24. Epelbaum, F.M.B., and Martinez, M.G. (2014). The technological evolution of food traceability systems and their impact on firm sustainable performance: A RBV approach. International Journal of Production Economics, Vol. 150, pp. 215-224. doi: 10.1016/ j.ijpe.2014.01.007.

25. Fainshmidt, S., and Frazier, M.L. (2017). What Facilitates Dynamic Capabilities? The Role of Organizational Climate for Trust. Long Range Planning, Vol. 50(5), pp. 550-566. doi: 10.1016/j.lrp.2016.05.005.

26. Fallon-Byrne, L., and Harney, B. (2017). Microfoundations of dynamic capabilities for innovation: a review and research agenda. Irish Journal of Management, Vol. 36(1), pp. 21 31. doi: 10.1515/ijm-2017-0004.

27. Gajendran, T., Brewer, G., Gudergan, S., and Sankaran, S. (2014). Deconstructing dynamic capabilities: the role of cognitive and organizational routines in the innovation process. Construction Management and Economics, Vol. 32(3), pp. 246-261. doi: 10.1080/ 01446193.2013.845306.

28. Grant, R.M. (1991). The Resource-Based Theory of Competitive Advantage: Implications for Strategy Formulation. California Management Review, Vol. 33(3), pp. 114-135. doi: 10.2307/41166664.

29. Grant, R.M. (1996). Toward a knowledge-based theory of the firm. Strategic Management Journal, Vol. 17(S2), pp. 109-122. doi: 10.1002/smj.4250171110.

30. Hart, S.L. (1995). A Natural-Resource-Based View of The Firm. Academy of Management Review, Vol. 20(4), pp. 986-1014. doi: 10.5465/amr.1995.9512280033. 
31. Hart, S.L., and Dowell, G. (2010). A Natural-Resource-Based View of the Firm: Fifteen Years After. Journal of Management, Vol. 37(5), pp. 1464-1479. doi: 10.1177/ 0149206310390219.

32. Hazarika, N., and Zhang, X. (2019). Evolving theories of eco-innovation: A systematic review. Sustainable Production and Consumption, Vol. 19, pp. 64-78. doi: 10.1016/ j.spc.2019.03.002.

33. Helfat, C.E., and Peteraf, M.A. (2003). The dynamic resource-based view: capability lifecycles. Strategic Management Journal, Vol. 24, pp. 997-1010. doi: 10.1002/smj.332.

34. Horbach, J. (2008). Determinants of environmental innovation - New evidence from German panel data sources. Research Policy, Vol. 37(1), pp. 163-173. doi: 10.1016/ j.respol.2007.08.006.

35. Huang, J.W., and Li, Y.H. (2017). Green Innovation and Performance: The View of Organizational Capability and Social Reciprocity. Journal of Business Ethics, Vol. 145(2), pp. 309-324. doi: 10.1007/s10551-015-2903-y.

36. Klewitz, J., and Hansen, E.G. (2014). Sustainability-oriented innovation of SMSs: a systematic review. Journal of Cleaner Production, Vol. 65, pp. 57-75. doi: 10.1016/ j.jclepro.2013.07.017.

37. Leonard-Barton, D. (1992). Core capabilities and core rigidities: A paradox in managing new product development. Strategic Management Journal, Vol. 13(S1), pp. 111-125. doi: $10.1002 / \mathrm{smj} .4250131009$.

38. Liao, J., Kickul, J.R., and Ma, H. (2017). Organizational Dynamic Capability and Innovation: An Empirical Examination of Internet Firms. Journal of Small Business Management, Vol. 47(3), pp. 263-286. doi: 10.1111/j.1540-627X.2009.00271.x.

39. Lichtarski, J. (2007). Podstawy nauki o przedsiębiorstwie. Wrocław: Wydawnictwo Akademii Ekonomicznej we Wrocławiu.

40. Li-Ying, J., Wang, Y., and Ning, L. (2016). How do dynamic capabilities transform external technologies into firms' renewed technological resources? - A mediation model. Asia Pacific Journal of Management, Vol. 33(4), pp. 1009-1036. doi: 10.1007/s10490-016-94699.

41. Meredith, S. (1995). Environmental Strategies in the Paint and Coatings Industry. Business Strategy and the Environment, Vol. 4, pp. 1-8. doi: 10.1002/bse.3280040102.

42. Pacheco, D.A.J., ten Caten, C.S., Jung, C.F., Ribeiro, J.L.D., Navas, H.V.G., and CruzMachado, V.A. (2017). Eco-Innovation determinants in manufacturing SMSs: Systematic review and research directions. Journal of Cleaner Production, Vol. 142, pp. 2277-2287. doi: 10.1016/j.jclepro.2016.11.049.

43. Penrose, E.T. (1959). The Theory of the Growth of the Firm. New York: John Wiley.

44. Pichlak, M. (2012). Uwarunkowania innowacyjności organizacji. Studium teoretyczne $i$ wyniki badań empirycznych. Warszawa: Difin.

45. Poznańska, K. (2018). Nowe formy innowacji. Warszawa: Oficyna Wydawnicza SGH. 
46. Segarra-Oña, M.V., Peiró-Signes, A., Albors-Garrigós, J., and Miret-Pastor, M. (2011). Impact of Innovative Practices in Environmentally Focused Firms: Moderating Factors. International Journal of Environmental Research, Vol. 5(2), pp. 425-434. doi: 10.22059/ IJER.2011.327.

47. Sopińska, A., and Dziurski, P. (2018). Postawy wobec zarządzania wiedzą w otwartych innowacjach. Przeglad Organizacji, $n r$ 7, ss. 25-30.

48. Teece, D.J. (2007). Explicating dynamic capabilities: the nature and microfoundations of (sustainable) enterprise performance. Strategic Management Journal, Vol. 28(13), pp. 1319-1350. doi: 10.1002/smj.640.

49. Teece, D.J., Peteraf, M.A., and Leih, S. (2016). Dynamic Capabilities and Organizational Agility: Risk, Uncertainty, and Strategy in the Innovation Economy. California Management Review, Vol. 58(4), pp. 13-35. doi: 10.1525/cmr.2016.58.4.13.

50. Teece, D.J., Pisano, G., and Shuen, A. (1997). Dynamic capabilities and strategic management. Strategic Management Journal, Vol. 18(7), pp. 509-533. doi: 10.1002/ (sici)1097-0266(199708)18:7<509::aid-smj882>3.0.co;2-z.

51. Triguero, A., Moreno-Mondéjar, L., and Davia, M.A. (2013). Drivers of different types of eco-innovation in European SMEs. Ecological Economics, Vol. 92, pp. 25-33. doi: 10.1016/ j.ecolecon.2013.04.009.

52. Wilden, R., and Gudergan, S.P. (2015). The impact of dynamic capabilities on operational marketing and technological capabilities: investigating the role of environmental turbulence. Journal of the Academy of Marketing Science, Vol. 43(2), pp. 181-199. doi: 10.1007/s11747-014-0380-y.

53. Wilden, R., Gudergan, S.P., Nielsen, B.B., and Lings, I. (2013). Dynamic Capabilities and Performance: Strategy, Structure and Environment. Long Range Planning, Vol. 46(1-2), pp. 72-96. doi: 10.1016/j.lrp.2012.12.001.

54. Winter, S.G. (2003). Understanding dynamic capabilities. Strategic Management Journal, Vol. 24, pp. 991-995. doi: 10.1002/smj.318.

55. Wójcik-Karpacz, A. (2017). Zdolności dynamiczne versus zdolności operacyjne. Organizacja i Kierowanie, nr 1(175), ss. 51-70.

56. Wysocki, J. (2019). Ekologizacja działalności produkcyjnej w strategiach rozwoju przedsiębiorstw w Polsce. Warszawa: Oficyna Wydawnicza SGH.

57. Xu, K., Sirmon, D.G., and Gao, S. (2010). R\&D Resources, R\&D Management, and Innovation: Evidence of Mediation. Paper presented at the American Academy of Management Conference, Montreal.

58. Zahra, S.A., Sapienza, H.J., and Davidsson, P. (2006). Entrepreneurship and Dynamic Capabilities: A Review, Model and Research Agenda. Journal of Management Studies, Vol. 43(4), pp. 917-955. doi: 10.1111/j.1467-6486.2006.00616.x. 
59. Zhang, J.A., and Walton, S. (2017). Eco-innovation and business performance: the moderating effects of environmental orientation and resource commitment in greenoriented SMEs. R\&D Management, Vol. 47(5), pp. E26-E39. doi: 10.1111/radm.12241.

60. Zhou, S.S., Zhou, A.J., Feng, J., and Jiang, S. (2019). Dynamic capabilities and organizational performance: The mediating role of innovation. Journal of Management \& Organization, Vol. 25(5), pp. 731-747. doi: 10.1017/jmo.2017.20.

61. Zollo, M., and Winter, S.G. (2002). Deliberate Learning and the Evolution of Dynamic Capabilities. Organization Science, Vol. 13(3), pp. 339-351. doi: 10.1287/ orsc.13.3.339.2780. 